level falls with advancing pregnancy allowance must be made for the stage of gestation at which the test is carried out, and a bilirubin value at 34 weeks that might indicate the need for active intervention would not necessarily have the same import at 24 weeks. Technical errors-for example, owing to exposure of liquor to daylight, to contamination with maternal or foetal blood, to interference by haemoglobin absorption, etc.-can be minimized by careful technique, but each laboratory needs to standardize and evaluate the method it uses.

Little is known of how bilirubin enters liquor or of its rate of turnover, but the water content changes rapidly, and if this were associated with variation in the total liquor volume, changes in the bilirubin value might be secondary to this.

Bilirubin is insoluble in water, and hence in liquor, as in plasma, it is attached to protein. Protein turnover in liquor amnii is slow in comparison with the water component, so theoretically could give an indirect measurement of liquor volume. Thus by relating bilirubin to protein as the bilirubin/ protein ratio errors secondary to changes in liquor volume would be eliminated. Dunstan (1968), however, did not find any relation between protein content and liquor volume.

The present study of two series of cases of $\mathrm{Rh}$ isoimmunization comprising 477 cases in all and using two different methods of protein estimation confirms that the bilirubin and protein values do correlate with severity of haemolytic disease, but that

\begin{tabular}{l} 
TABLE VI.-Protein Levels in Liquor Amnii-Summary of Results in \\
Present and Two Relevant Published Series \\
\hline \\
\end{tabular}

F \& $\mathrm{C}=$ Folin and Ciocalteau technique. bilirubin is superior to protein and is not improved, indeed is impaired, by relating to protein values.

Because these findings are in direat conflict with those of the other two groups of workers cited, we have considered whether technical differences in protein estimation between the three laboratories could be the explanation. A direct comparison of the protein values in these series is summarized in Table VI.

For the three laboratories the mean values are not different, though the ranges differ. This is probably because the published figures are based on extremely small series, but the method of selecting patients for amniocentesis may also have played a part.

We therefore conclude that the estimation of protein in liquor amnii does not give as good a forecast of severity of haemolytic disease as is possible by bilirubin estimation and that the value of bilirubin is not improved by relating it to the protein value.

Acknowledgements are made to obstetric colleagues at the Princess Mary Maternity Hospital and General Hospital, Newcastle upon Tyne, and to the staff of the laboratory of the children's department.

REFERENCES

Cherry, S. H., Kochwa, S., and Rosenfield, R. E. (1965). Obstet. and Gynec., 26, 826.

Dunstan, M. K. (1968). 7. Obstet. Gynaec. Brit. Cwlth, 75, 732.

Knox, E. G., Fairweather, D. V. I., and Walker, W. (1965). Clin. Sci. 28, 147 .

Liley, A. W. (1963). Amer. F. Obstet. Gynec., 86, 485.

Morris, E. D., Murray, J., and Ruthven, C. R. J. (1967). Brit. med. f., 2, 352 . Papadopoulos, N. M., Hess, W. C., O'Dohenty, D., and MoLane, J. E.
(1959). Clin. Chem., 5, 569.

Scott, P. (1959). A.C.B. Newsletter, November.

Stempfel, R., and Zetterström, R. (1955). Pediatrics, 16, 184.

Walker, W. (1968). 尹. Obstet. Gynaec. Brit. Cwlth, 75, 1207.

Walker, W., Fairweather, D. V. I., and Jones, P. (1964). Brit. med. f., 2, 141 .

Wild, A. E. (1961). Clin. Sci., 21, 221.

\title{
Sickle-cell Anaemia, Sickle-cell Thalassaemia, Sickle-cell Haemoglobin C Disease, and Asymptomatic Haemoglobin C Thalassaemia in one Ghanaian Family
}

\author{
F. I. D. KONOTEY-AHULU,* M.B., M.R.C.P., D.T.M.\&H.; BELA RINGELHANN, $†$ M.D., CAND.MED.SCI.
}

Cummary : A Ghanaian family is described in which a $S$ sickle-cell haemoglobin C man married to a sicklecell thalassaemia woman produced 12 children (eight alive). Four children have sickle-cell anaemia, two sicklecell haemoglobin $C$ disease, one has sickle-cell thalassaemia, and one is asymptomatic haemoglobin $C$ thalassaemia.

It is emphasized that the contribution that adult sicklecell disease patients make, through procreation, to the persistence of the $S$ gene may be greater than is normally supposed, and that this contribution may soon outstrip that made by balanced polymorphism through falciparum malaria. Widespread haemoglobin genotyping in schools leading to genetic counselling is advocated to decrease the incidence of sickle-cell disease.

* Lecturer, Department of Medicine and Therapeutics, Ghana Medical School, Accia ; Physician, Korle Bu Teaching Hospital, Accra. In receipt of grant from International Atomic Energy Agency (Vienna). t Senior Lecturer, Department of Pathology, Ghana Medical School, Accra.

\section{Introduction}

Ghana abounds in abnormal haemoglobins. One person in four or five has either the sickle-cell trait (Hb AS) or the haemoglobin $\mathrm{C}$ trait (Hb AC). For West Africa as a whole Lehmann (1954) described the incidence of the sickle-cell trait as between 20 and $30 \%$. Edington and Laing (1957) made the incidence of the sickle-cell trait in Southern and Northern Ghana to be $19 \%$ and $7 \%$ respectively. Edington and Lehmann (1954a, 1954b) first described $\mathrm{Hb} \mathrm{C}$ outside the U.S.A. The main focus for $\mathrm{Hb} \mathrm{C}$ is in West Africa (Allison, 1956a, 1956b ; Neel et al., 1956), with the highest frequency in Northern Ghana of $20-21 \%$ (Edington and Lehmann, 1956; Edington and Laing, 1957 ; Neel, 1957).

The most recent surveys in Ghana involved young adults from the north and south of the country. In the south frequency of the sickle-cell trait (AS) is $20 \%$ and the $\mathrm{Hb} \mathrm{C}$ trait (AC) is $9 \%$, while in the north (among 143 persons) $\mathrm{Hb}$ AS is $7 \%, \mathrm{Hb} \mathrm{AC}$ is $18 \%, \beta$-thalassaemia is $4-5 \%$, with one case of $\alpha$-thalassaemia (Ringelhann et al., 1968). Other 
qualitative or quantitative haemoglobinopathic genes that have been described as being found in Ghana include High $F$ gene (Edington and Lehmann, 1955b), Hbs D, G, and $\mathrm{K}$ (Edington,

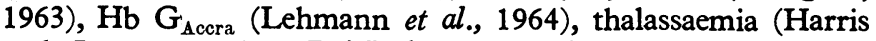
and Lomax, 1954 ; Boi-Doku and Ofori-Atta, 1967), and recently a new haemoglobin variant-haemoglobin Korle $\mathrm{Bu}$, $\alpha_{2} \beta_{2} \quad{ }^{73 A s p} \rightarrow$ Asn (Konotey-Ahulu et al., 1968). With at least nine abnormal haemoglobin genes in Accra it is not surprising that various genotype combinations have been seen and described-namely, SS, SC, S-thalassaemia, S+F (in children), $\mathrm{SF}_{\text {highgene }}$ (in adults), $\mathrm{CC}, \mathrm{CF}_{\text {highgene, }}$ and, recently, thalassaemia major (Boi-Doku and Ofori-Atta, 1967), GG Accra $_{\text {(Lehmann }}$ et al., 1964), $\mathrm{SD}_{\text {Punjab }}$ (Ringelhann et al., 1967), and $\mathrm{Hb} S$ Korle $\mathrm{Bu}$ in two successive generations (Konotey-Ahulu et al., 1968). If one includes the G-6-PD enzyme defect the incidence of hereditary qualitative and quantitative erythrocyte defects rises to one in three persons in Ghana.

This paper describes yet another gene interaction in Ghana, $\mathrm{Hb} \mathrm{C}$ thalassaemia occurring in one member of a remarkable family of 14 (10 alive), none of whom has a normal haemoglobin genotype.

\section{The Family}

The family (Figs. 1 and 2), who now live 15 miles $(24 \mathrm{~km}$.) from Accra, belong to the Fante tribe. They were investigated because one of the children presented at the sickle-cell clinic of Korle Bu Hospital on 17 March 1967 with symptoms and

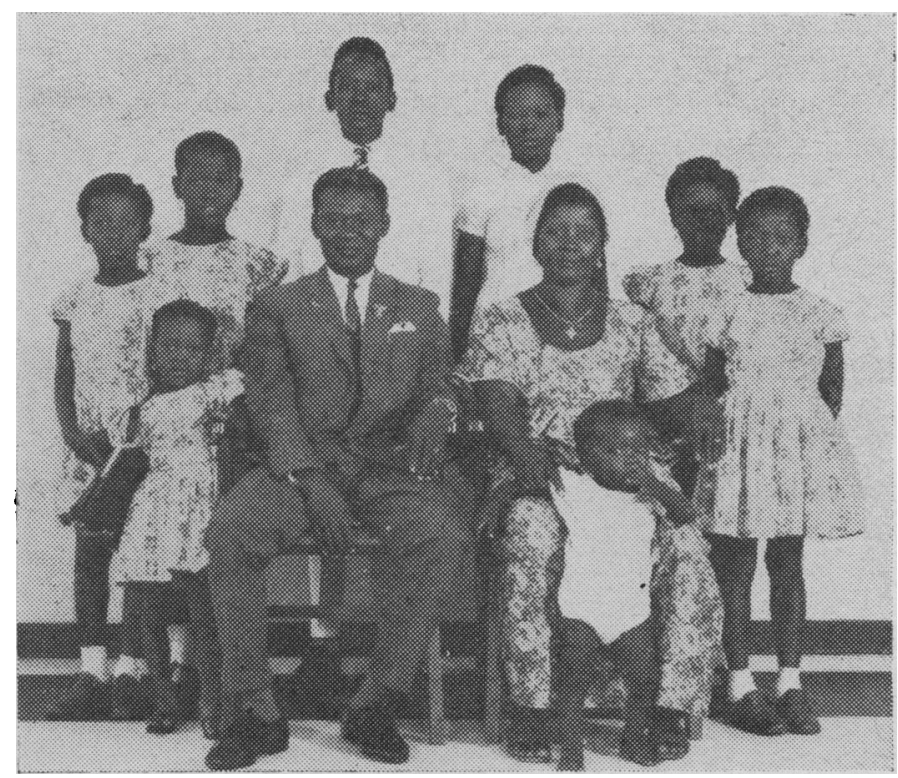

FIG. 1.-The family. Back row, left to right: II $8, \mathrm{Hb} \mathrm{SC}$; II $7 \mathrm{Hb} \mathrm{C}$ thal ; II 3, Hb SS; II 2, Hb SS ; II 6, Hb SS. Front row, left to right: II $11, \mathrm{Hb}$ SC ; I 1, Hb SC; I 2 , $\mathrm{Hb}$ S-thal; II $12, \mathrm{Hb} S \mathrm{right}$; and extreme signs of sickle-cell anaemia. Table I summarizes the clinical features of the family. Table II gives the mother's obstetric history.

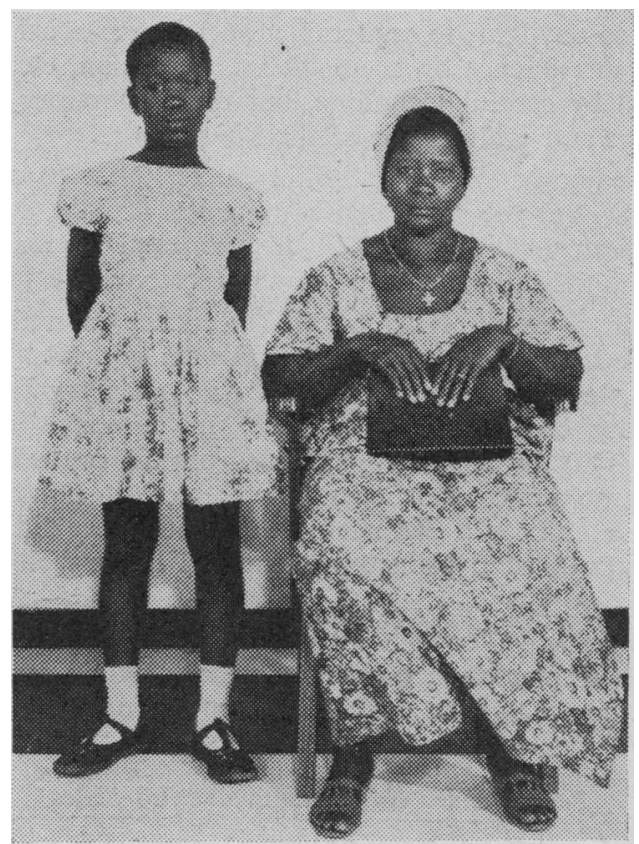

FIG. 2.-39-year-old sickle-cell thalassaemia mother with 10-year-ald haemoglobin $\mathrm{C}$ thalassaemia daughter, both healthy looking.

TABLE II.-Mother's Obstetric History

\begin{tabular}{|c|c|c|}
\hline $\begin{array}{l}\text { Preg- } \\
\text { nancy }\end{array}$ & Delivery & Subsequent History of Child \\
\hline $\begin{array}{l}1 \text { st } \\
\text { 2nd } \\
\text { 3rd } \\
\text { 4th }\end{array}$ & $\begin{array}{ll}\text { Normal. } & \text { Female } \\
\text { Normal. } & \text { Female } \\
\text { Normal. } & \text { Male } \\
\text { Normal. } & \text { Female }\end{array}$ & $\begin{array}{l}\text { 1. Died suddenly aged } 1 \text { month } \\
\text { 2. Alive. } 19 \text { yrs. Sickle-cell anaemia (SS) } \\
\text { 3. Alive. } 17 \text { yrs. Sickle-cell anaemia (SS) } \\
\text { 4. Died at } 6 \frac{1}{2} \text { yrs. after brief febrile illness }\end{array}$ \\
\hline 5th & $\underset{\text { Nemales }}{\text { Normal. Twin }}\{$ & $\begin{array}{l}\text { 5. One died at } 3 \frac{1}{2} \text { yrs. Convulsions and fever } \\
\text { 6. Other twin alive. } 12 \text { yrs. old. Sickle-cell anaemia } \\
\text { (SS) }\end{array}$ \\
\hline $\begin{array}{l}\text { 6th } \\
\text { 7th } \\
\text { 8th } \\
\text { 9th }\end{array}$ & $\begin{array}{l}\text { Normal. Female } \\
\text { Normal. Female } \\
\text { Normal. Female } \\
\text { Premature. Male }\end{array}$ & $\begin{array}{l}\text { 7. Alive. } 10 \text { yrs. Haemoglobin C thalassaemia } \\
\text { 8. Alive. } 8 \text { yrs. Sickle-cell Hb C disease (SC) } \\
\text { 9. Alive. } 7 \text { yrs. S-thalassaemia } \\
\text { 10. Born at } 8 \text { months' cyesis after mother had severe }\end{array}$ \\
\hline 10th & Normal. Female & $\begin{array}{l}\text { rheumatic crisis. Died after } 3 \text { days } \\
\text { 11. Alive and well. } 4 \text { yrs. Sickle-cell Hb C disease } \\
\text { (SC) }\end{array}$ \\
\hline 11th & Normal. Male & 12. Alive. 1 yr. old. Sickle-cell anaemia (SS) \\
\hline
\end{tabular}
Note: 12 children, 4 dead, 8 alive with $4 \mathrm{Hb} \mathrm{SS}, 1 \mathrm{Hb}$ S-thal., $2 \mathrm{Hb} \mathrm{SC}$, and
$1 \mathrm{Hb}$ C-thal.

\section{Investigations and Results}

The haematological profiles are given in Table III. All 10 peripheral blood films showed target cells (between 1 and $20 \%$ ); the least number was found in sickle-cell anaemia and sicklecell thalassaemia, and the largest number where haemoglobin $\mathrm{C}$ occurs-namely, SC disease and C-thalassaemia (compare red cell fragility results below). Anisocytosis, poikilocytosis, and

TABLE I.-Clinical Features of Family

\begin{tabular}{|c|c|c|c|c|c|c|c|c|c|}
\hline Subject & Age & Sex & $\begin{array}{l}\text { Weight } \\
\text { lb. (kg.) }\end{array}$ & $\begin{array}{l}\text { Conjunc- } \\
\text { tival Pallor }\end{array}$ & Jaundice & $\begin{array}{l}\text { Lymph- } \\
\text { adenopathy }\end{array}$ & $\begin{array}{l}\text { Palpable } \\
\text { Liver }\end{array}$ & $\begin{array}{l}\text { Palpable } \\
\text { Spleen }\end{array}$ & Remarks \\
\hline $\begin{array}{ll}\text { I } & 1 \\
\text { I } & 2\end{array}$ & $\begin{array}{l}40 \\
39\end{array}$ & $\stackrel{\mathbf{M}}{\mathbf{F}}$ & $\begin{array}{l}143(65) \\
159(72)\end{array}$ & $\begin{array}{l}\text { Nil } \\
\text { Yes }\end{array}$ & $\begin{array}{l}\mathrm{Nil} \\
\mathrm{Nil}\end{array}$ & $\begin{array}{l}\mathrm{Nil} \\
\mathrm{Nil}\end{array}$ & Nil. & $\begin{array}{l}\text { Nil } \\
\text { Nil }\end{array}$ & $\begin{array}{l}\text { Healthy SC father. Joint pains rarely } \\
\text { Healthy looking S-thal mother. Late men. }\end{array}$ \\
\hline II 2 & 19 & $\mathbf{F}$ & $101(46)$ & Yes & Yes & Nil & Yes & Nil & Small size; SS. Late menarche. Joint pains \\
\hline $\begin{array}{ll}\text { II } & 3 \\
\text { II } & 6 \\
\text { II } & 7 \\
\text { II } & 8\end{array}$ & $\begin{array}{r}17 \\
12 \\
10 \\
8\end{array}$ & $\begin{array}{l}\mathbf{M} \\
\mathbf{F} \\
\mathbf{F}\end{array}$ & $\begin{array}{l}107\left(48 \frac{1}{2}\right) \\
56 \frac{1}{2}\left(25 \frac{1}{2}\right) \\
72 \frac{1}{2}(33) \\
50 \frac{1}{2}(23)\end{array}$ & $\begin{array}{l}\text { Yes } \\
\text { Yes } \\
\text { Nil } \\
\text { Nil }\end{array}$ & $\begin{array}{l}\text { Yes } \\
\text { Yes } \\
\text { Nil } \\
\text { Nil }\end{array}$ & $\begin{array}{l}\text { Nil } \\
\text { Yes } \\
\text { Nil } \\
\text { Yes }\end{array}$ & $\begin{array}{l}\text { Yes } \\
\text { Yes } \\
\text { Nil } \\
\text { Nil }\end{array}$ & $\begin{array}{l}\text { Nil } \\
\text { Nil } \\
\text { Nil } \\
\text { Nil }\end{array}$ & $\begin{array}{l}\text { Joint pains often. SS } \\
\text { Joint pains very often. Small size. SS } \\
\text { Never complained. Healthiest of all. C-thal } \\
\text { Joint pains rarely. Epistaxis. Dental caries. }\end{array}$ \\
\hline II 9 & 7 & $\mathbf{F}$ & 51 (23) & Yes & Nil & Yes & Yes & Nil & Joint pains once when she had pneumonia. \\
\hline II 11 & 4 & $\mathbf{F}$ & 31 (14) & Nil & Nil & Nil & Nil & Nil & $\begin{array}{l}\text { S-thal } \\
\text { Sever complained. " Square-shaped" skull. }\end{array}$ \\
\hline II 12 & 1 & $\mathbf{M}$ & $21(10)$ & Nil & Nil & Nil & Yes & Yes & "No trouble." ss \\
\hline
\end{tabular}




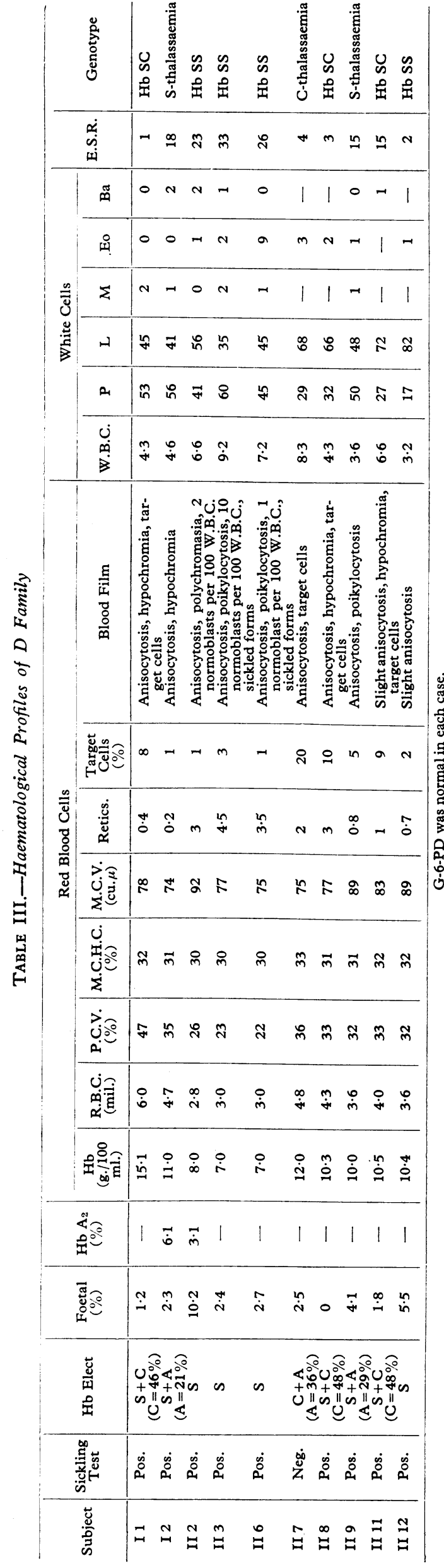

hypochromia were common. Sickled forms were seen in the plain film only in two $\mathrm{Hb}$ SS patients who also had the lowest haemoglobin and haematocrit values. Only the father (healthy SC) and one daughter (healthy C-thalassaemia) had haemoglobins of $12 \mathrm{~g} . / 100 \mathrm{ml}$. or more, with equivalently high haematocrits. There were no malaria parasites.

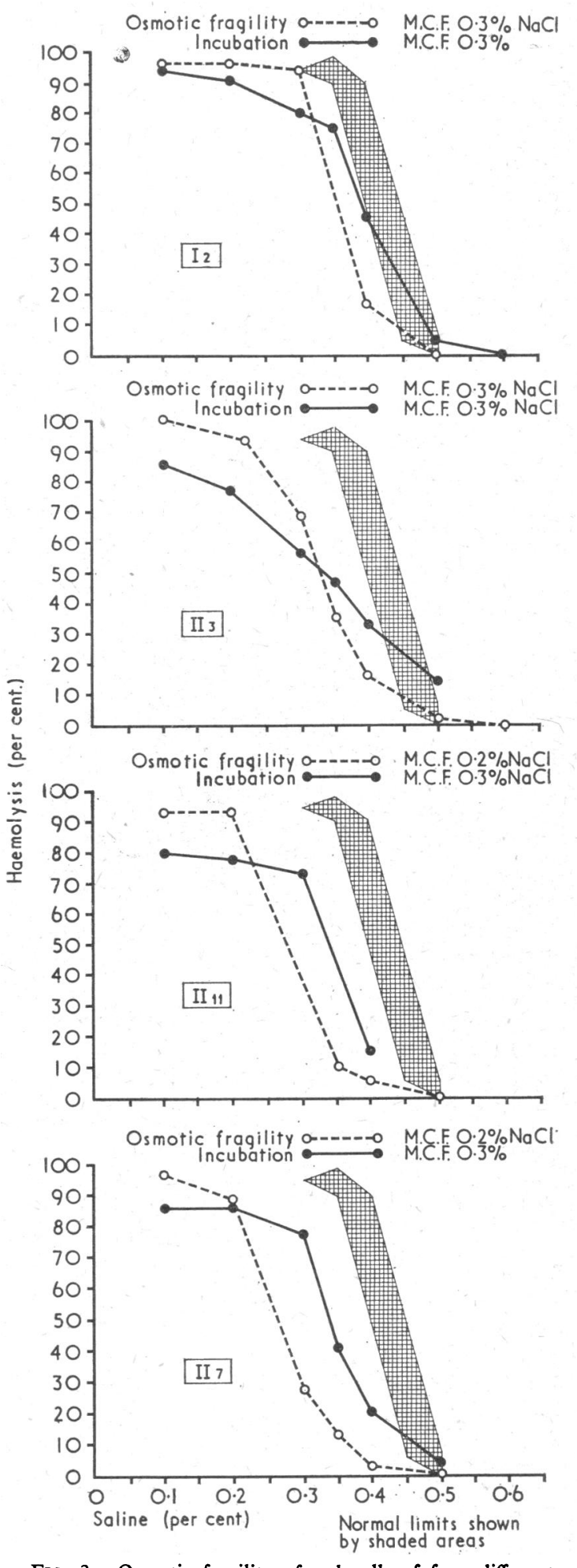

FIG. 3-Osmotic fragility of red cells of four different haemoglobinopathies. Note fragility is least where haemoglobin $C$ is present. Resistance to fragility progresses $\mathrm{S}$-thal $<\mathrm{SS}<\mathrm{SC}<\mathrm{C}$-thal.

Red cell fragility test was performed by the same technician on all the 10 samples on the same day. Osmotic fragility was not only decreased in all samples compared with normal-that is, the red cells were in all patients more resistant 
to haemolysis than normal-but there seemed to be a definite pattern in the degree of resistance, thus $\mathrm{S}$-thal $<\mathrm{SS}<\mathrm{SC}<\mathrm{C}$-thal (see Fig. 3).

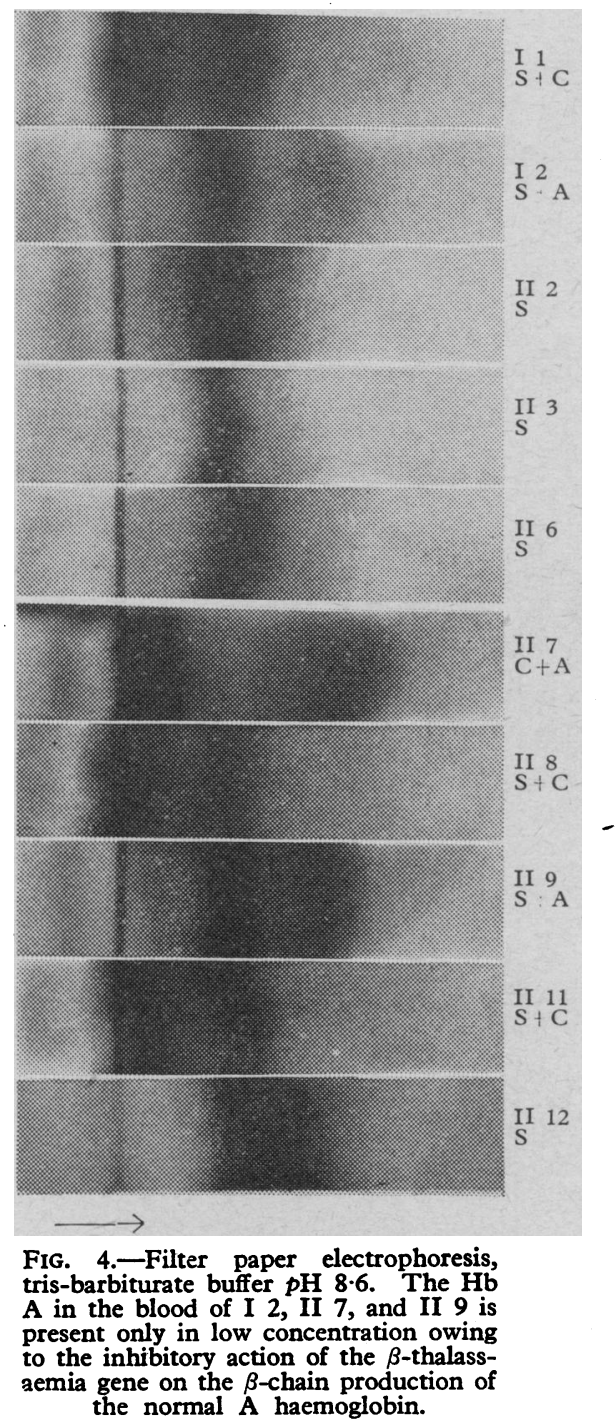

Haemoglobin electrophoresis was carried out on filter paper on a vertical Durrum type cell, with tris-barbiturate buffer at $p H ~ 8.6$ (Fig. 4), and tris-borate buffer at $p \mathrm{H} 8.9$ (Fig. 5). Where necessary starch-gel electrophoresis was carried out (Fig. 6) by the method of Poulik (1957), $\mathrm{Hb} \mathrm{A}_{2}$ determination by the method of Marengo-Rowe (1965), and quantitative determination of $\mathrm{Hb} \mathrm{A}$ was made according to Ringelhann and Makunga (1965). The results show that not one member of the entire family of 10 has the normal genotype AA. The father (I 1) is SC and the mother (I 2) S-thalassaemia. The children come out SS (II 2, 3, 6, and 12), SC (II 8 and 11), S-thalassaemia (II 9), and C-thalassaemia (II 7) (Fig. 4).

\section{Discussion}

When an adult with sickle-cell haemoglobin $\mathrm{C}$ disease marries another with sickle-cell thalassaemia four different haemoglobinopathies may be, theoretically, expected in the offspring: SS, S-thalassaemia, SC, and C-thalassaemia. Provided the law of averages was obeyed and enough children resulted from the marriage one might expect these haemoglobinopathies to occur in roughly equal numbers. It is impossible to tell the genotypes of the four children who died out of 12 in this family, but it is not unexpected that of the eight alive all the four haemoglobinopathies are represented (Fig. 7). It is

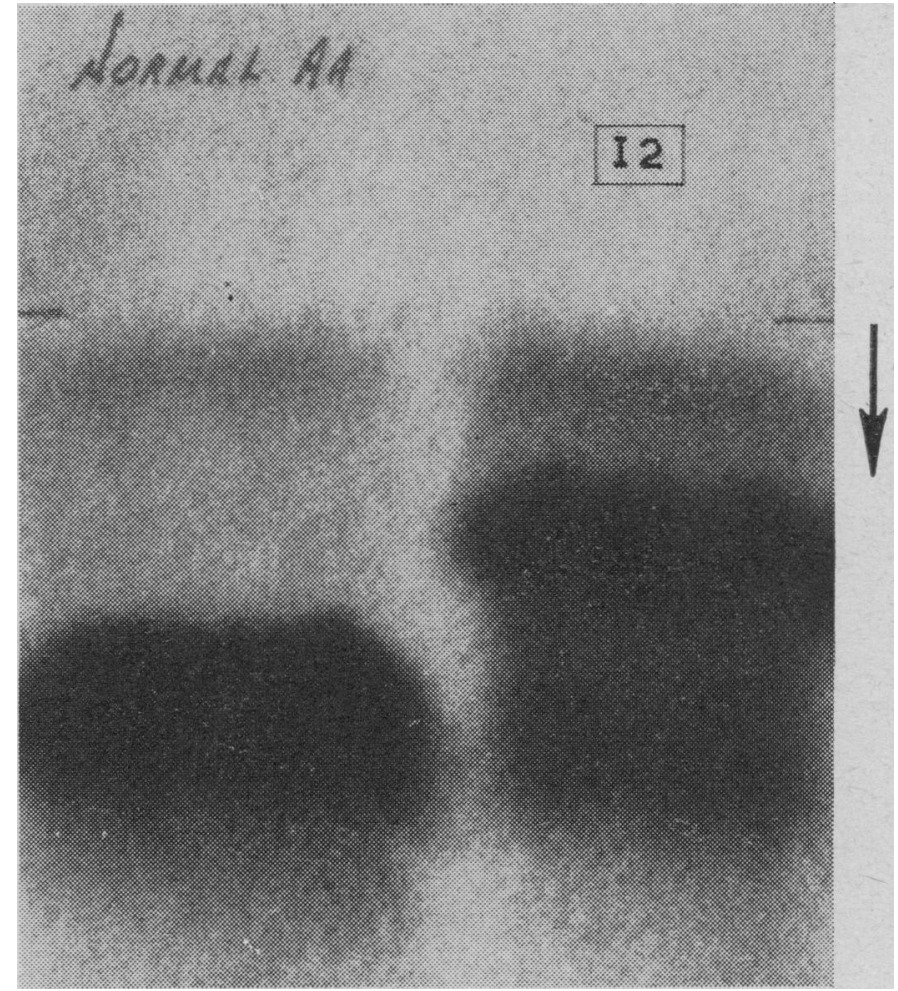

FIG. 5.-Filter paper electrophoresis, tris-borate buffer $p$ H 8.9. The $\mathrm{Hb} \mathrm{A}_{2}$ in the blood sample of $\mathrm{I} 2$ is higher, $6.1 \%$, than in the normal control, $2 \cdot 1 \%$ (left).

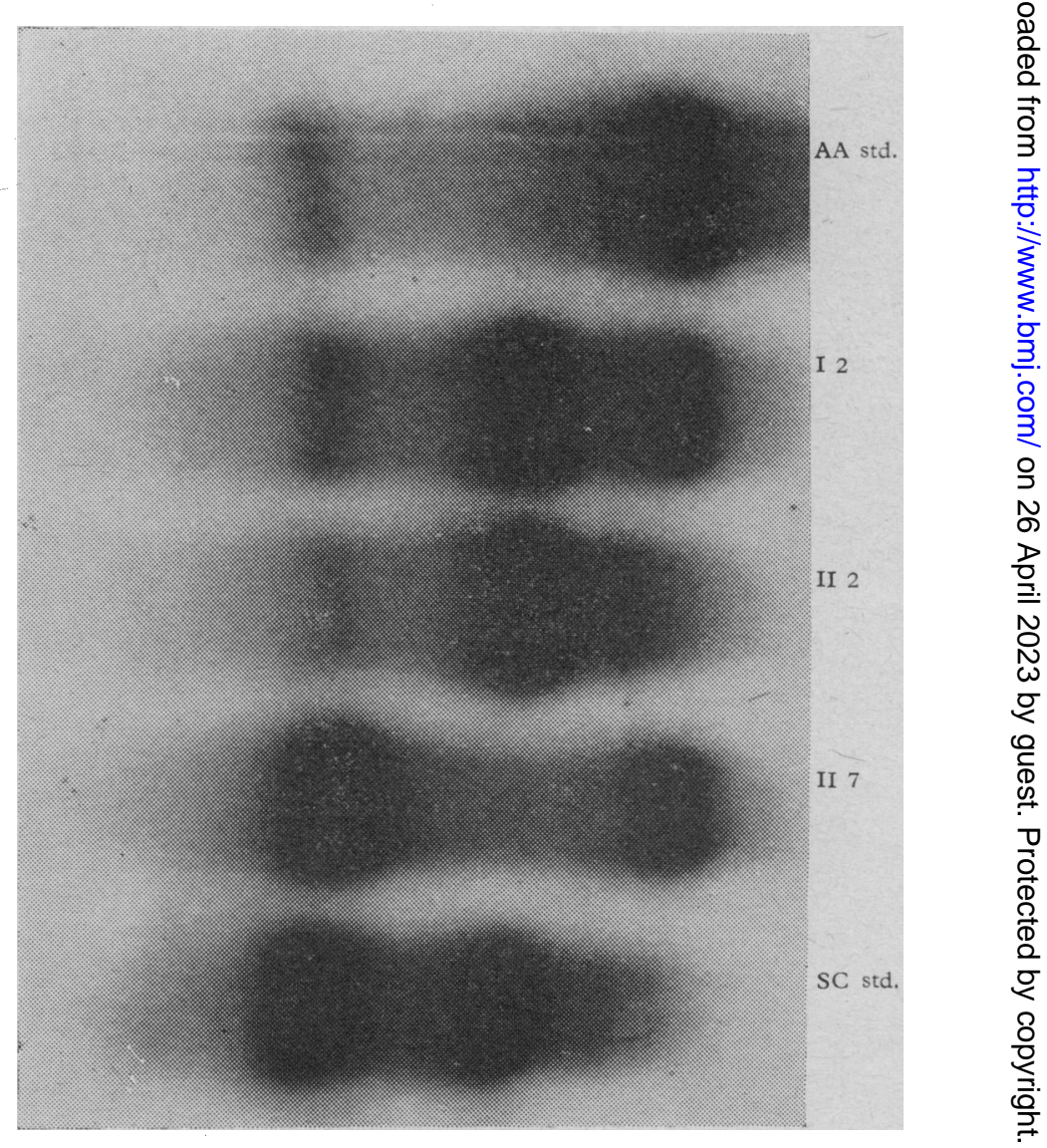

FIG. 6.- Starch-gel electrophoresis $p \mathrm{H}$ 8.3. - The $\mathrm{Hb} \mathrm{A}_{2}$ is higher in the blood of I 2 (S-thalassaemia), compared with the control (AA) and II 2 (SS). In the latter there is a small $F$ fraction between $A$ and $S$. $\mathrm{Hb} C$ does not separate from $A_{2}$ at this $p H$ in the tlood of II 7 (C-thalassaemia). 
not impossible to predict the haemoglobin genotype from the symptomatology in a place like Accra, where definite patterns of disease occur. Thus SC disease can often be distinguished clinically from adult cases of sickle-cell anaemia (Table IV),

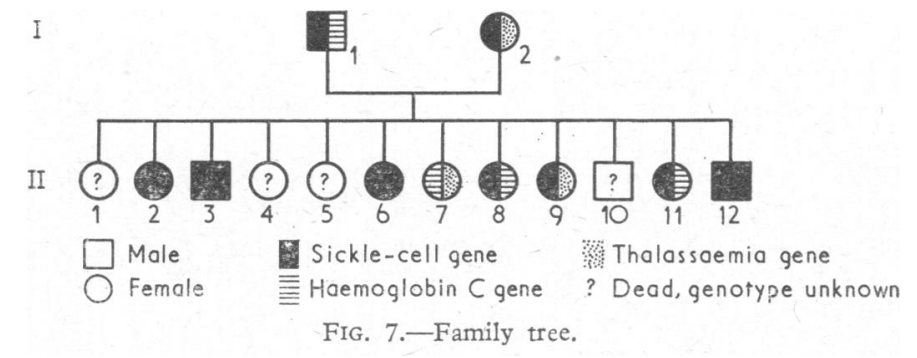

TABLE IV.-Clinical Differentiation of Adult $H b S S$ and $H b S C$

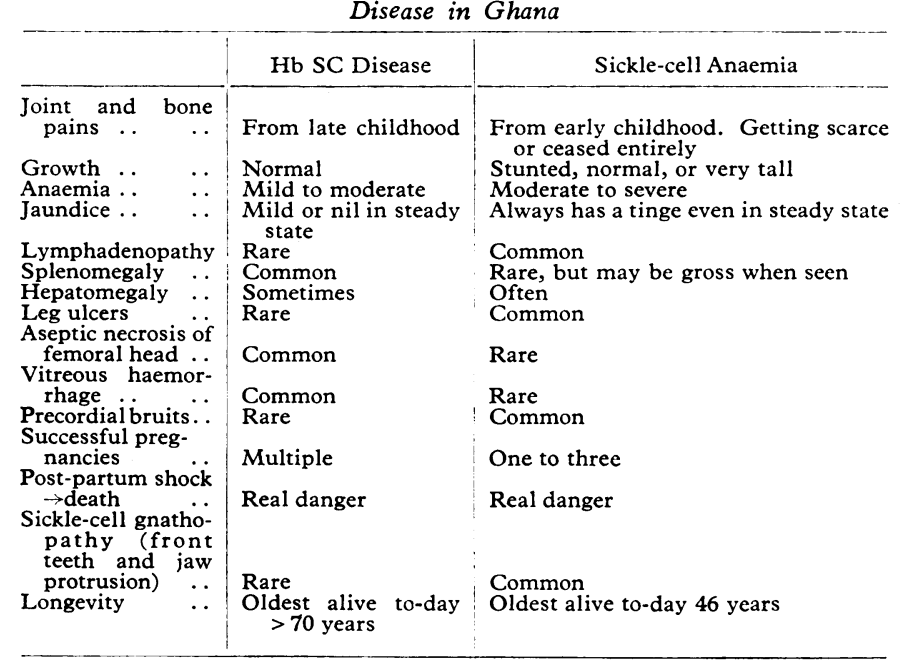

and the latter from sickle-cell thalassaemia and $S F_{\text {highgene }}$ (Table V). The almost complete absence of joint pain history in the oldest girl (II 2), who otherwise has all the features of sickle-cell anaemia, can be explained by the high percentage $(10 \cdot 2)$ of foetal haemoglobin. The course of sickle-cell anaemia is milder when the proportion of $\mathrm{Hb} \mathrm{F}$ is high.

We thought at first from the history that the mother was $\mathrm{Hb} \mathrm{SC}$, because of the sheer numbers of her children, but as it turned out she is the first sickle-cell thalassaemia patient on record with 11 pregnancies and 12 children (eight alive), none of the deliveries taking place in hospital. The combination of sickle-cell disease and thalassaemia has not only "seldom been reported in pregnancy but the condition of women with this combined haemoglobinopathy is believed to deteriorate during gestation" (Dunn and Haynes, 1967). However, Hendrickse and Watson-Williams (1966) state that "increasing anaemia near term, preventable by folic acid administration, is the only hazard."
We have often seen $\mathrm{Hb}$ SC patients fare worse than $\mathrm{Hb}$ SS patients of the same age and sex. This is because of the varying standards of living in different families. An SC patient from a background with a bad soçial history (broken homes, poverty, unintelligent parents, etc.) has a poor medical history, while an SS patient from a good home may go from year to year without a single crisis. This family provides a remarkable built-in control: the children live under the same roof, are bitten by the same mosquitoes, and are given the same tender care by the same diligent, intelligent, Methodist parents. Given the same circumstances it can be seen from the clinical features and blood profiles that sickle-cell anaemia is the most severe disease, followed by SC and S-thalassaemia diseases, and the. least severe is C-thalassaemia. Our particular C-thalassaemia girl is completely asymptomatic and would pass for a normal healthy Ghanaian schoolgirl ; so is the SC father, whose $\mathrm{Hb}$ of $15.1 \mathrm{~g} . / 100 \mathrm{ml}$. is not unusual of Ghanaian SC haemoglobinopathy in the steady state.

Haemoglobin $\mathrm{C}$ thalassaemia is very rare ; only 31 cases were recorded in the world press by 1965 . In their detailed review of 24 cases from the literature Russo and Mollica (1965) observed that 17 were of the black race and seven were white, with the age range from 8 months to 68 years. Most of them were clinically anaemic, but at least three had haemoglobin values above $12 \mathrm{~g} . / 100 \mathrm{ml}$. In half of them the spleen was palpable. Red cell osmotic resistance was invariably increased, and target cells plus anisopoikilocytosis were constant features. The type of thalassaemia present in almost all cases was $\beta$-thalassaemia. This is the case in the present family where $A_{2}$, has been shown to be raised in the $S$-thalassaemia mother.

The comparatively excellent health of our C-thalassaemia patient and her S-thalassaemia mother, who was capable of passing through 11 pregnancies unscathed, may be due to the remarkable variability of the clinical results of the simultaneous inheritance of the traits of thalassaemia and a $\beta$-chain variant. Humble et al. (1954) found that, within the same family, $S$-thalassaemia could either produce an anaemia or be entirely symptomless. Almost asymptomatic adult sickle-cell disease patients are not uncommonly found in Ghana. Even with sickle-cell anaemia, which is reputed to kill patients before they are of childbearing age, our experience is similar to that of Serjeant et al. (1968), who reported " relatively benign sicklecell anaemia in 60 patients aged over 30 in the West Indies." We think this is because of the rising standard of living as emphasized by the Ghana Medical fournal (1964).

Frequency and severity of crises get less as sickle-cell anaemia (SS) patients get older, and this may cause confusion with other haemoglobinopathies that may also be returned "SS" on paper electrophoresis. Notable among these is the $\mathrm{SF}_{\text {highgene }}$ which was first described, also from Accra, by Edington and Lehmann (1955a, 1955b). This is a benign condition in which haemoglobin $S$ together with a high level of foetal haemoglobin persists into adult life. Other reports from Africa were by Jacob and Raper (1958) in Uganda and Thompson and

Table V.-Differential Diagnosis of Adult $\mathrm{Hb}$ " $S S$ " Patients in Ghana

\begin{tabular}{|c|c|c|c|c|}
\hline \multicolumn{2}{|l|}{ True Genotype } & \multirow{2}{*}{ 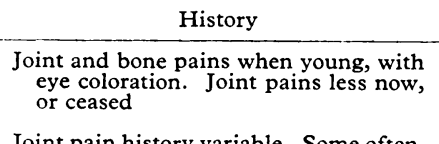 } & Physical Examination & Special Investigations \\
\hline SS $\ldots \quad \ldots$ & . & & $\begin{array}{l}\text { Anaemia, jaundice, leg scars. May be stunted, } \\
\text { normal, or very tall. Women may have borne } \\
1 \text { or } 2 \text { children. Gnathopathy is the rule. } \\
\text { Typically no spleen }\end{array}$ & $\begin{array}{l}\text { Sickling }+. \text { Electrophoresis } S \text { or } S+F . \text { Blood } \\
\text { profile typical. (Family study) }\end{array}$ \\
\hline$S$ - $\beta$-thalassaemia & . & $\begin{array}{l}\text { Joint pain history variable. Some often, } \\
\text { others nil }\end{array}$ & $\begin{array}{l}\text { May be like SS or may look quite normal and } \\
\text { healthy. Spleen may be palpable. Women may } \\
\text { have many children }\end{array}$ & 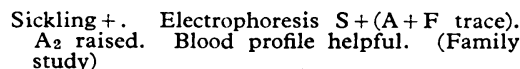 \\
\hline SF thalassaemia & . & Joint pains rare or never & $\begin{array}{l}\text { May be anaemic or look normal. Rarely jaun- } \\
\text { diced. Spleen may be palpable. Women may } \\
\text { have many children }\end{array}$ & $\begin{array}{l}\text { Sickling }+. \text { Electrophoresis } \mathbf{S}+(\mathbf{A}+\mathbf{F}) . \\
\quad \mathbf{A}_{2} \text { not } \\
\text { raised. High \% F. Kleihauer test-hetero- } \\
\text { geneous cell stain. (Family study) }\end{array}$ \\
\hline $\mathrm{SF}_{\text {highgene }}$ & $\cdots$ & Joint pains rare or never & $\begin{array}{l}\text { May be anaemic from other causes, or be quite } \\
\text { normal. Not jaundiced. Women capable of } \\
\text { having many children }\end{array}$ & $\begin{array}{l}\text { Sickling }+ \text {. Electrophoresis S }+\mathrm{F} \text {. High } \% \mathrm{~F} \text {. Hing } \\
\text { Kleihauer test-homogeneous staining of cells. } \\
\text { Normal profile. (Family study) }\end{array}$ \\
\hline SD Punjab $\cdots$ & $\cdots$ & Joint pains as in SS when young & $\begin{array}{l}\text { (Our } 2 \text { patients are still young, but behave like } \\
\text { Hb SS) }\end{array}$ & $\begin{array}{l}\text { Sickling +. Blood profile like SS. Paper and } \\
\text { starch-gel electrophoresis, S. Agar-gel electro- } \\
\text { phoresis pH } 6 \text { "A+S." Solubility tests. } \\
\text { Fingerprinting of } \mathrm{Hb} \text { (Family study) }\end{array}$ \\
\hline S Korle Bu & . & Never had joint pains & Normal. Women have several children & $\begin{array}{l}\text { Fingerprinting. Normal blood profile. Sick- } \\
\text { ling }+. \text { (Family study) }\end{array}$ \\
\hline
\end{tabular}


Lehmann (1962) from Accra, while Went and MacIver (1958) described it from the West Indies. The differential diagnosis of adult sickle-cell disease reported "SS" is given in Table V. Clinically some cases of sickle-cell F-thalassaemia may be difficult to differentiate from $\mathrm{SF}_{\text {highgene }}$ cases, but the simple Kleihauer and Betke staining technique (Lehmann and Huntsman, 1966) will distinguish between the two by their foetal haemoglobin distribution in the red cells. In F-thalassaemia the distribution of $\mathrm{Hb} F$ in the individual red cells is quite heterogeneous, while in $\mathbf{F}_{\text {highgene }}$ it is relatively uniform. We have found this test useful in Accra, where the level of $\mathrm{Hb} \mathrm{F}$ may be more than $10 \%$ in sickle-cell anaemia or sickle-cell .thalassaemia.

The contribution that adult sickle-cell disease patients make towards the persistence of the $S$ gene in the population is greater than is usually realized. It is no mere conjecture when we state that here in Ghana this contribution will soon outstrip that supposed to be made by balanced polymorphism through falciparum malaria. Widespread haemoglobin genotyping starting from schools and subsequent genetic counselling of young adults ought to be pursued relentlessly (Konotey-Ahulu, 1968) if the morbidity and mortality caused by sickle-cell disease are to be appreciably reduced on the African Continent.

We are grateful to Professor H. Lehmann, M.R.C. Abnormal Haemoglobin Unit, University Department of Clinical Biochemistry, Cambridge, for his advice; to Miss P. Kynoch (Cambridge): for technical advice and help; and to Professor S. R. A. Dodu, Head of Department of Medicine and Therapeutics, Ghana Medical School, for his encouragement.

\section{REFERENCES}

Allison, A. C. (1956a). Ann. hum. Genet., 21, 67.

Allison, A. C. (1956b). Trans. roy. Soc. trop. Med. Hyg., 50, 185.

Boi-Doku, F. S., and Ofori-Atta, Susan (1967). Ghana med. F., 6, 45.

Dunn, J. M., and Haynes, R. L. (1967). Amer. F. Obstet. Gynec., 97, 574 .

Edington, G. M. (1963). Ghana med. f., 2, 83.

Edington, G. M., and Laing, W. N. (1957). Brit. med. 7., 2, 143.

Edington, G. M., and Lehmann, $\mathrm{H}$. (1954a). Lancet, 2, 173.

Edington, G. M., and Lehmann, H. (1954b). Trans. roy. Soc. trop. Med. Hyg., 48, 332 .

Edington, G. M., and Lehmann, H. (1955a). Brit. med. 7., 1, 1308.

Edington, G. M., and Lehmann, H. (1955). b). Brit. med.' F., 2, 1328.

Edington, G. M., and Lehmann, H. (1956). Man, 56, 34.

Ghana med. F., 1964, 3, 1 .

Ghana med. F., 1964, 3, 1. G. D. (1954). W. Afr. med. 7., 3, 29.

Harris, F. C., and Lomax, G. D. (1954). W. Afr. med. F., 3, 29. Obstet. Gynec., 94," 739 .

Humble, J. G., Anderson, I., White, J. C., and Freeman, T. (1954). F. clin. Path. 7, 201.

Jacob, G. F., and Raper, A. B. (1958). Brit. F. Haemat., 4, 138.

Konotey-Ahulu, F. I. D. (1968). Ghana med. F., 7, 118.

Konotey-Ahulu, F. I. D., Gallo, E., Lehmann, H., and Ringelhann, B. (1968). 7. med. Genet., 5, 107 .'

Lehmann, H. (1954). Eugen. Rev., 46, 101. 203, 363 .

Lehmann, H., and Huntsman, R. G. (1966). Man's Haemoglobins, p. 293. Amsterdam.

Marengo-Rowe, A. J. (1965). F. clin. Path., 18, 790.

Neel, J. V. (1957). New Engl. F. Med., 256, 161.

Neel, J. V., Hiernaux, J., Linhard, J., Robinson, A., Zuelzer, W. W., and Livingstone, F. B. (1956). Amer. 尹. hum. Genet., 8, 138.

Poulik, M. D. (1957). Nature (Lond.), 180, 1477.

Ringelhann, B., Dodu, S. R. A., Konotey-Ahulu, F. I. D., and Lehmann, H. (1968). Ghana med. f., 7, 120.

Ringelhann, B., Lewis, R. A., Lorkin, P. A., Kynoch, P. A. M., and Lehmann, H. (1967). Acta haemat. (Basel), 38, 324.

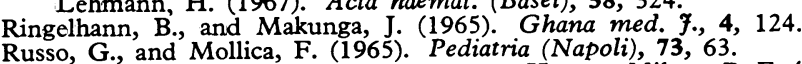

Serjeant, G. R., Richards, R., Barbor, P. R. H., and Milner, P. F. (1968). Brit. med. F., 3, 86.

Thompson, G. R., and Lehmann, H. (1962). Brit. med. F., 1, 1521.

Went, L. N., and MacIver, J. E. (1958). Blood, 13, 559.

\title{
Outbreak of Brucella melitensis Type 2 Infection in London
}

\author{
N. S. GALBRAITH,* M.B., D.P.H. ; M. S. ROSS, $\dagger$ M.R.C.S., L.R.C.P., F.C.PATH. \\ R. R. DE MOWBRAY, $\ddagger$ M.D., M.R.C.P. ; D. J. H. PAYNE, § M.B., F.C.PATH.
}

Brit. med.F., 1969, 1, 612-614

Summary : An outbreak of seven cases of Brucella melitensis infection in London was traced to Italian pecorino cheese (cheese made from unpasteurized sheep's milk) which had been obtained from village markets in central Italy, brought back to England, and distributed to the affected persons.

It is emphasized that pecorino cheese made from unpasteurized milk should not be eaten unless it is known to have been stored for at least 90 days, the period during which these cheeses have been shown to become free from viable brucella organisms.

\section{Introduction}

An outbreak of seven cases of Brucella melitensis type 2 infection took place in November and December 1965 in persons of Italian origin resident in West Ham, London. The only food common to all the affected persons was pecorino cheese which had been obtained in August 1965 from village markets in central Italy.

\footnotetext{
* Deputy Medical Officer of Health, Newham, London E.15.

t Pathologist, Queen Mary's Hospital, London E.15.

† Physician, Queen Mary's Hospital, London E.15.

\$ Director, Public Health Laboratory, Portsmouth.
}

We report this outbreak because $B r$. melitensis is rare in the United Kingdom (Dalrymple-Champneys, 1960) and because it appears that this is the first recorded outbreak where the patients have acquired their infection in this country.

\section{The Outbreak}

The seven patients, four adults and three children (see Table), belonged to two Italian families who had lived in West Ham for many years; five persons in these two families were not affected. Three of the patients and one of the unaffected persons visited relatives in central Italy in August 1965, and brought home with them two pecorino cheeses. All the affected persons consumed the cheese. Two other Italian households consisting of four adults and three children were also given some of the cheese; all were symptom-free and none had serological evidence of brucella infection.

The two pecorino cheeses were purchased from two village markets in the last few days of August 1965 and were brought back to England on 2 September. They were eaten from the latter part of September onwards, being served grated on spaghetti. A small sample of one of the cheeses, which was remaining in January 1966, was examined but no brucella organisms were isolated. Serum samples from two relatives in central Italy, who regularly purchased pecorino cheese from 